\title{
Good Will and Spontaneity in Communication ${ }^{1}$
}

\author{
NERIJUS STASIULIS \\ Department of Philosophy and Cultural Studies, Faculty of Creative Industries, Vilnius Gediminas Technical University, 1 Traku Street, \\ 01132 Vilnius, Lithuania \\ Email: nerijus.stasiulis@vilniustech.It
}

\begin{abstract}
The article is based on the interpretation of Kant's notion of good will with regard to its meaning for successful communication. It seeks to delineate its necessary relation to spontaneity as opposed to a strictly closed definition - the spontaneity in language as crucial for communication. Agambenian and Wittgensteinian musings on language and paradigm are employed for that purpose. The art of comedy is seen to illustrate the communication based on spontaneity and paradigm and the art of tragedy is seen to depict the condition of radical incommunicability. Alongside this linguistic and epistemological approach, the discussion of the issue also includes the ontological aspect, i. e. the Agambenian-Aristotelian notion of potentiality is described as akin to the Kantian good will (Ding an sich) and is seen as the necessary (and perhaps also sufficient) condition for (successful) communication.
\end{abstract}

Keywords: communication, good will, spontaneity, language, paradigm

\section{INTRODUCTION}

The main problematic philosophical question of the article is the following: how is succesful communication in general possible? Or, to formulate it differently, what are the a priori conditions for successful communication? Additional problematic questions concern the role of language in communication. Is language necessary for communication as well as namely successful communication? Is language sufficient for it? If language is to be means of successful communication, what characteristics should it possess? By 'successful' (communication) I mean such which is conducive to a greater (an, ideally, perfect) unity between members of communication. Accordingly, by 'unsuccessful' I mean such which fails to contribute to such a unity and rather supports disunity or discord. Also, strictly speaking, I make no difference between successful communication and communication as such because, based on the definition of communication which I accept in this article, communication must be successful if it is to be properly called communication: an unsuccessful communication is no communication at all but merely miscommunication in which nothing is truly communicated.

1 The article is based on the presentation of the same name in the International Conference VISUALITY 2021: MEDIA AND COMMUNICATION (22-23 April 2021). 
In the following paragraphs I shall sketch the basics of a philosophical theory of communication in an attempt to answer the above-mentioned questions.

Following Giorgio Agamben's insight, I hold that communication and language are distinct in the sense that language is superfluous in terms of communication. As all animals know, language is not necessary for communication. Language can even hinder communication. According to Arvydas Šliogeris who famously called Man the son of nothingness, language arose from nothingness in Man and it can in principle arise even if there existed but one human being in the entire world (Šliogeris 2008). Hence, I shall see language as an isolating or possibly isolating force, or, at any rate, such a phenomenon which is strongly bound to the possibility of individuation and isolation of people from one another. Thus, language is situated between the unity of beings which allows them to communicate successfully and the difference or separation of beings which hinders their successful communication. The problem of unity and difference, by its very nature, is ontological. Ontology is the theory of Being, but our access to Being is essentialy linguistic and made possible for us only because we are speaking creatures, i.e. beings which have language. Hence, what I shall attempt to discuss is namely the ontological conditions for successful communication, that is, what should our relation to language be for it to swing towards the pole of unity from the pole of difference?

Man is the only animal which has language and anthropogenesis coincides with the appearance of language. With this linguistic essence all other cultural traits of man appear. Thus, Man is also the only animal which can laugh and which has art. Both artistic representation and laughter must have to do with language. We shall seek to situate communication, which for man is necessarily linguistic, between the phenomena and arts of comedy and tragedy. We shall do so because we assume that, on the one hand, the possibility of laugher has to do with the linguistic nature of Man and, on the other hand, laughter is a very social phenomenon. Thus, we shall look in the comedic language and the comedic art in general, that is, in the structure of comedy, for the key to successful communication. With a little resemblence to Bergson's notion of laughter, we shall see laughter as opposed to what was mechanical stiffness (of the intellect) for Bergson and for us it will be language limited to the finitude of a strict and stiff definition. The latter will be shown to have structural correspondence to tragedy, i.e. the art which is directly opposed to comedy. I will regard tragedy and comedy as necessarily linked and, likewise, the definite and the indefinite in language to be necessarily linked. The definite in language structurally corresponds to the finite, limited and isolated in ontological terms, whereas the indefinite in language structurally corresponds to the infinite, unlimited and communicative in ontological terms. The paradigm for this link of the definite and the indefinite in language is Kant's notion of the scheme which unites the finite concept and the infinite sensibility. It is this 'mysterious' inbetween which is also the window of the Kantian good will which we shall try to expose as key to successful communication.

Philosophical aspects of communication are also discussed in Ercolini (2016), Greer (2017), Carvalho (2017), Kačerauskas (2018; 2018a; 2019; 2020), Vabalaitė (2019), Kačerauskas, Mickūnas (2020) and Niederbacher (2020).

\section{THE BASIC STRUCTURES OF COMEDY AND TRAGEDY AS THE TWO POLES OF COMMUNICA- TION AND MISCOMMUNICATION}

What did I. Kant mean by good will (Kant 2017: 5)? Or, why is good will, according to the Könnigsbergian thinker, the only source of morality? What must 'morality' mean in order to 
be based solely on good will? For Kant, morality is what makes the common world possible - the common world as diametrically opposed to the condition of war of every man against every man. Hence, it is precisely what makes successful communication possible. The common world and the radical war are the two ideal poles between which the being of the world fluctuates. We shall define here the condition of war (of every man against every man) as a condition of radical incommunicability, and the condition of 'good will' or 'morality' as the opposite of this radical incommunicability, that is, as successful communication. The access to the good will (which, for Kant, seems to reside in the thing-for-itself) is the ontological condition of communication. Communication, obviously, means only successful communication, because otherwise it is but miscommunication, that is, not communication. And, crucially, we shall hold that these two options are exhaustive, that is, there is nothing apart from either communication or miscommunication - only perhaps shades or variants thereof in between.

One strategy of accessing this good will in attempt to arrive at perfect communicability is to discard language in general. The Kantian L. E. J. Brouwer (cf. 1996: 402) in his work 'Life, Art and Mysticism', the chapter on language, describes successful communication as unity of wills, and, for him, when there is unity of wills, language is no longer necessary or, at any rate, it only follows and expresses the unity of wills. We shall follow his suggestion and shall consider unity of different beings to be the condition for communication. But, as will be evident in the following paragraphs, we will differ from Brouwer in that we will not suggest discarding language in order to arrive at this unity but a change of the way language is perceived and used.

First, I shall discuss the pole and meaning of incommunicability, or miscommunication. I believe it is grasped by the philosopher of language G. Agamben's state of exception. A man in the state of exception is radically abandoned, it is outside of any community, completely alone. Still, he maintains a relation to the community: according to the famous Agambenian definition, the man in the state of exception is included in the community by being excluded from it. Exception is included by means of its very exclusion.

Interestingly, I find this same structure or possibility of the human condition expressed in the art of tragedy: the fate of the tragic hero depicts complete abandonment, or 'being taken out of context' - he or she is suddenly and unexpectedly, and, obviously, dramatically, transposed into utter isolation, his or her relation to the social structure being completely destroyed in the crucial moment. The tragic hero is a human being in the state of exception. But, also, the exposition of this very possibility of the human condition (this very possibility of radical incommunicability) points to the need of resolving the dramatic difference: this very same fate or moment of the 'downfall' of the tragic hero inversely depicts the preciousness of the social bond and structure, and points to the virtue of reconciliation (see Sachs 2021).

Now, if we attempt to look for the other pole, that is, for the structure of communicability, it is only logical to look for it in the opposite of the state of exception as well as in the art opposed to tragedy. For Agamben, the opposite of the state of exception is the paradigm, or example (Agamben 2002). According to the Italian thinker, example is not just any member of a class but such a member which is taken away from the class to illustrate its whole. For example, rosa, rosae, rosam... is an example to illustrate what the first declination in Latin is. As an example, it is no longer a member of the class ('its reference is neutralized') but is excluded from it. It is excluded by means of its very inclusion. So, the exception is included by means of exclusion; and paradigm is excluded by means of its inclusion. 
If we follow this reasoning, the structure of the paradigm (opposite of the state of exception) must also coincide with that of comedy (opposite of tragedy). Two conditions must be met for something to be funny. Firstly, what causes us to laugh is always something bad or painful, shameful, etc. in one way or another. Secondly, this painful thing is at the very same moment perceived as harmless. That is, this same painful thing is not perceived as a member of the class of painful things but as an example, or paradigm, of a painful thing. In fact, perhaps the essence of humour/laughter is expressed best in the case of tickling - as if the quasi most harmful attack against the weakest places in the body is simultaneously or momentously rendered harmless, neutralised, turned into an example of itself. The same kind of thing happens with every case of laugher at a life event or a joke: something incongruous and painfully sensitive to one is immediately perceived as (now) harmless, and the relief and victory over it is expressed as laughter, or - better said, perhaps - is laughter. As in the moment of the downfall of the tragic hero we intuituvely grasp the pole of radical incommunicability (the state of exception of the tragic hero), so in the moment of the mishap of the comical character we grasp the opposite pole to this radical incommunicability, that is, a tragic (painful) moment with a neutralised reference. What causes me to laugh is the painful thing, the reference of which is neutralised. Comedy is tragedy which has turned into a paradigm, i. e. the comic is the neutralising exhibition of the tragic. Or, to put it differently, comedy is irony with respect to tragedy. It structurally corresponds to the irony with respect to language because we have defined language as the separating, or differentiating, factor.

As we see laugher and comedy as the most sociable and the socialising force, we hold the relation of people in laugher to be the other pole to the condition of radical incommunicability. It involves irony with respect to our basic separated condition and, thus, with respect to language itself which always serves to separate rather than unite. But irony with respect to language does not amount to an attempt to discard language. Just like the structure of comedy presupposes that of tragedy (because comedy is neutralised tragedy), so the structure of successful communication, which must transcend language, presupposes our very linguistic existence. Hence, the question arises: what should our language be like in order not to move to the pole of miscommucation but rather to the pole of (successful) communication?

We shall attempt to sketch an answer to this question in the following chapter.

\section{COMMUNICATION AS NON-PRIVATE AND BASED ON PARADIGM}

Our main premise in this chapter is that our linguistic capability of forming rigorous definitions of words corresponds to our epismological possibility of seeing the world as composed of strictly defined and delimited entities as well as to ontological revelation of beings, including ourselves, as strictly defined and delineated individuals, having clear boundaries from one another (cf. Stasiulis 2014: 65-67). Hence, we shall see language based on rigorous definitions as equiprimordial with the isolating view of entities, including ourselves, and as necessarily conducive to miscommunication because rigorously defined language tends to gravitate towards a merely private language. So, here we will combine our insights of the previous chapter with the insights of the great critic of both a private language and a rigorously defined language of Ludwig Wittgenstein. We shall see Wittgensteinian critique as opening the way for a better use of language more apt for successful communication. We should move from a rigorously defined language which structurally corresponds to the separating force exhibited in the art of tragedy to a language the use of which is based not on definitions but on a paradigm whose uniting force is exhibited in the art of comedy. 
We find a clue for such a use of language in the philosophophy of language of Ludwig Wittgenstein. Interestingly, Wittgenstein once said that entire philosophy could consist of a series of jokes (Witze). Because the working of a language game - the congruent following of an unarticulated rule - is based precisely on the ability to follow a paradigm. In order to use words and sentences correctly (meaningfully), we must have 'the lightning speed of thought', or the immediate sense of how to play a language game, how to follow the rule or the paradigm. And the funniness of a joke consists precisely in recognising that here, in this one particular case, language is used not according to its rule, outside of its context, outside of its natural home, is 'on a day off' (but in a (now) harmless way). We could say that Wittgenstein's philosophical activity consists in a humorous exhibition of the tragedy of mind immersed in pseudoproblems or in a view of language which assumes that words must have rigorously defined meanings.

Crucially for our analysis in the context of communication, Wittgenstein shows that the latter view of language implies that such language is only private. Thus, it structurally corresponds to the state of separatedness, incommunicability and the tragic that we have described above. Thus it strikes us as quite natural that, for Wittgenstein, language use based on a paradigm is at home only in its social context because the rules of the use of language are both 1) necessarily public and 2) cannot be caged in a rigorous definitions of words. We must also bear in mind that Wittgenstein's critique of language amounts to a critique of the Cartesian solipsistic subject. By our definition, this notion of a solipsistic subject is the very epistemological and ontological source of miscommunication.

This change of seeing language is also well illustrated in the way Wittgenstein sees mathematics (construed as mathematical activity, or language game). Even mathematics, which we have been used to seeing as the standard for rigorously defined entities, arises from our natural form of life and our natural ability to engage in the activity of counting and to recognise or establish certain stable regularities we encounter in the world (Bangu 2021). Counting, mathematics presupposes a form of life and a language game, which itself is rooted in activity and instinct (in something 'animal'). Still, empirical regularities that we have recognised can be 'hardened' into a rule and into a standard. Analogously, words and kinds can be given a definition but at the root of this processs lies the origin of the word from a language game and living activity. The language game itself is based on unarticulated rules which operate according to the logic of paradigm - the use of the word revolves around its family of resemblances. It is essentially non-private but part of our common form of life.

Hence, we suggest in this article that successful communication is only possible with a language bases on paradigm and not a language based on definition. Still, paradoxically, paradigm does not exclude definition but rather makes it into the proverbial Heraclitean river water, which stays ever the same only while being ever in flux. Wittgenstein (1972) also gives an analogy ( $\$ 96$ and further) of a river to describe the role of definite standards in [definition based] science: they are like river banks which are steady and provide the furrow for the river to flow, but the same pieces of the earth which once were parts of the stable bank can now be carried by the river flow, and the other pieces, which were carried aflow before, are now turned into stable banks.

It is up to the Cartesian subject to be solipsistic and to enclose the meaning of a word into a private definition. Language based on a definition is necessarily solipsistic. Language based on a paradigm is necessarily social. The language games hold us in common. 


\section{THE SOCRATIC EROS AND THE KANTIAN GOOD WILL}

We would like to close this article by referring to the way the great Greek thinker Plato joined the themes of successful communication (which he terms love, the semantic field of which is covered by the Greek words eros, filia, among others) and comedy and tragedy. We assume that the filia of ancient Greek philosophers refers to the common form of life as the a priori condition of (successful) communication. Socrates in Plato's Symposium situates the theme of love between those of comedy and tragedy and describes love - or communication - as a daemon, who is both poverty and plenty, both nothingness and isness, and it is for this reason that Plato in the work emphasizes the unity of tragedy and comedy. Tragedy stands for the particular and isolated (or abandoned), while comedy stands for the general and social. It is in the field of tension between the two that communication arises.

This paradoxical stance of communication is also expressed by a well-known ancient Greek saying: My friends, I don't have a single friend! Kant, whose good will we also assume to take place in this paradoxical in-between, explains the meaning of this saying in one of his letters:

A love like that wants to communicate itself completely, and it expects of its respondent a similar sharing of heart, unweakened by distrustful reticence. That is what the ideal of friendship demands. But there is something in us which puts limits on such frankness, some obstacle to this mutual outpouring of the heart, which makes one keep some part of one's thoughts locked within oneself, even when one is most intimate. The sages of old complained of this secret distrust - 'My dear friends, there is no such thing as a friend!' (quoted from Marshal: 2016). ${ }^{2}$

The problem is precisely this remainder in communication which does not allow us to be fully frank and possibly prevents the most fulfilling form imaginable that communication could take: the unity of souls, described by Aristotle as a single soul in two bodies or hinted at in Aristophanes' speech about the primordial unity of the opposites. This remainder is the reason why language has been an object of suspicion by many a thinker (like Brouwer, mentioned above) - it has been described as superficial, artificial, dead or deadening.

2 In the letter, Kant continues:

We can't expect frankness of people, since everyone fears that to reveal himself completely would be to make himself despised by others. But this lack of frankness, this reticence, is still very different from dishonesty. What the honest but reticent man says is true, but not the whole truth. What the dishonest man says is something he knows to be false. Such an assertion is called, in the theory of virtue, a lie. It may be harmless, but it is not on that account innocent. It is a serious violation of a duty to oneself; it subverts the dignity of humanity in our own person, and attacks the roots of our thinking (quoted from Marshal: 2016).

To add, if the state of exception equals the state of incommunicability and the tragic, or abandoned, state, then its opposite - the paradigm, or comedy - equals the state of successful communication. If tragedy includes by exclusion and thus points to the virtue of reconciliation, then comedy, which excludes by inclusion, points to the distance presupposed by every nearness, or the alienation presupposed by every successful communication. We shall call it the virtue of modesty, or shyness (And this why, on the contrary, tragedy arises from hybris).

We shall also note that the state of exception, or tragedy, corresponds to understanding (intellectus), or the principle of individuation (categorisation), while the paradigm, or comedy, corresponds to vitality, or spontaneity. By pointing out this crucial connection between the state of exception and tragedy, on the one hand, and the paradigm and comedy, on the other hand, we leave behind the seeming dualism (and I also refer here to the treatment of laughter by Bergson); we could speak of, to use Agamben's term, the field of tension between rule and life, the state of exception and the paradigm.

In terms of communication, it is the field of tension between distance, or radical incommunicability, and nearness, or complete communicability. 
But, based on our situating language in between the isolation of tragedy and the communicability of comedy, here we shall rather understand this 'uncommunicable' remainder positively - as the very potentiality to speak which is the urge we feel to communicate and to arrive at a perfect communication. According to Agamben (and Aristotle), the potentiality for an action is never exhausted in the action but always remains beyond it. The potentiality for language is never exhausted in speaking. Just like isolation is never exhausted in communicating. Conversely, this is why no definition is ever final, or at least, it is never the source of itself. Pure definition would throw us into the solitude and incommunicability of private language. Pure spontaneousness would throw us into the Dionysian pandemic frenzy dismissed from the aristocratic and limiting glance of the Apollo. But the spontaneousness of a language game, which follows the rule based on the infinity of non-exhaustive potentiality, which is synonymous with friendship or filia, is the Kantian golden medium which the Koenigsbergian philosopher must have meant when he spoke of good will.

\section{CONCLUSIONS}

We have set good will and the commonality of will as key to successful communication. Good will, which is at the root of practical and ethical reasoning, is situated between the abstractness of defined concepts and the spontaneity as well as multiplicity of possible situations. Thus, it is situated between purely linguistic existence and purely animal or 'sensual' existence. This is what makes communication a problem for Man but at the same time potentially makes it indeed rewarding. The art of tragedy expresses the intuition of the problem of purely linguistic 'human' existence while the art of comedy points to the solution of this problem. The key to successful communication lies in the irony with respect to both purely linguistic language and romantic languageless approach.

Received 14 September 2021

Accepted 6 December 2021

\section{References}

1. Agamben, G. 2002. What is a Paradigm? Available at: https://www.youtube.com/watch? $\mathrm{v}=\mathrm{G} 9 \mathrm{Wxn}-$ 1L9Er0\&list=PLBE227E32DBC7CA58

2. Bangu, S. 2021. Ludwig Wittgenstein: Later Philosophy of Mathematics. Available at: https://iep.utm.edu/ wittmath/

3. Bergson, H. 2014. Juokas. Vilnius: Vaga.

4. Brouwer, L. E. J. 1996. 'Life, Art, and Mystycism', Notre Dame Journal of Formal Logic 37(3): 389-429.

5. Carvalho, T. A. 2019. 'The Metaphysics of Communicative Action: A Critique of Habermas's Moral Theory', Revista Portuguesa de Filosofia 75(1): 447-476.

6. Ercolini, G. L. 2016. Kant's Philosophy of Communication. Duquesne.

7. Greer, E. A. 'Many-Sided Substance: The Philosophy of Conversation in Woolf, Russell, and Kant', Journal of Modern Literature 40(3): 1-117.

8. Kačerauskas, T.; Mickūnas, A. 2020. In Between Communication Theories Through One Hundred Questions. Basel: Springer.

9. Kačerauskas, T. 2018. „Luomai ir klasės medijų aplinkoje komunikacijos diskursų požiūriu“, Logos 96: 109-117.

10. Kačerauskas, T. 2018a. „Komunikacija ir perspektyvizmas“, Logos 97: 65-71.

11. Kačerauskas, T. 2019. 'Ethics in Business and Communication: Common Ground or Incommensurable?' E+M Ekonomie a Management 22 (1): 72-81.

12. Kačerauskas, T. 2020. „Tiesos klausimas komunikacijoje“ [The Issue of Truth in Communication], Logos 102: 70-76.

13. Kant, I. 2017. Groundwork for the Metaphysic of Morals. Trans. J. Bennett. Available at: https://www.earlymoderntexts.com/assets/pdfs/kant1785.pdf 
14. Marshall, C. 2016. Dear Immanuel - Kant Gives Love Advice to a Heartbroken Young Woman (1791). Available at: https://www.openculture.com/2016/02/kant-gives-advice-to-heartbroken-young-woman-after-sheloses-her-lover.html

15. Niederbacher, B. 2020. 'Exemplarist Virtue Theory and the Kant Complaint', Revista Portuguesa de Filosofia 76(1): 68-75.

16. Plato. 2013. Symposium. Trans. B. Jowett. Available at: https://www.gutenberg.org/files/1600/1600h/1600-h.htm

17. Sachs, J. 2021. Aristotle: Poetics. Available at: https://iep.utm.edu/aris-poe/

18. Schopenhauer, A. 1995. The World as Will and Idea. Trans. J. Berman. Everyman Paperbacks.

19. Stasiulis, N. 2014. Aristotelio filosofijos reikšmé Heideggerio mąstyme. Doctoral Thesis. Vilnius: VU leidykla.

20. Šliogeris, A. 2008. Niekis ir Esmas. I tomas. Vilnius: Apostrofa.

21. Vabalaitè, R. M. 2019. „Tikrosios savasties paieškos Karlo Jasperso filosofijoje“ [The Search for True Selfhood in Karl Jaspers's Philosophy], Logos 100: 68-75.

22. Wittgenstein, L. 1972. On Certainty. Trans. D. Paul and G. E. M. Anscombe. Harper Torchbooks.

NERIJUS STASIULIS

\title{
Gera valia ir spontaniškumas komunikacijoje
}

\begin{abstract}
Santrauka
Straipsnis pagrịstas Kanto geros valios sampratos aiškinimu, atsižvelgiant ị jos reikšmę sèkmingai komunikacijai. Siekiama nubrèžti jos būtino ryšio su spontaniškumu, priešingu griežtai uždarai apibrèžčiai, kontūrą - kalbos spontaniškumą kaip esmingą komunikacijai. Tam tikslui pasitelkiami agambeniški ir vitgenšteiniški kalbos ir paradigmos apmąstymai. Komedijos menas laikomas komunikacijos, paremtos spontaniškumu ir paradigma, iliustracija, o tragedijos menas - vaizduojančiu radikalaus nekomunikuojamumo būklę. Kartu su lingvistine ir epistemologine prieiga šios problemos aptarimas apima ir ontologini aspektą, t. y. G. Agambeno ir Aristotelio potencijos sąvoka aprašoma kaip gimininga Kanto gerai valiai (daiktui savyje), ji yra laikoma būtina (o galbūt ir pakankama) (sèkmingos) komunikacijos sąlyga.
\end{abstract}

Raktažodžiai: komunikacija, gera valia, spontaniškumas, kalba, paradigma 